\title{
Luminescent Properties of $\left[\mathrm{UO}_{2}(\mathrm{TFA})_{2}(\mathrm{DMSO})_{3}\right]$, a Promising Material for Sensing and Monitoring the Uranyl Ion
}

\author{
Pablo Martín-Ramos ${ }^{a, b}$, Ana L. Costa ${ }^{c}$, Manuela Ramos Silva ${ }^{b}$,Laura C. J. Pereira ${ }^{\text {, }}$ \\ Pedro S. Pereira da Silva ${ }^{b}$ J. Sergio Seixas de Meloc, Jesús Martín-Gil
}

\author{
${ }^{a}$ Escuela Politécnica Superior de Huesca - EPSH, Universidad de Zaragoza - UNIZAR, \\ Carretera de Cuarte s/n, 22071, Huesca, Spain. \\ ${ }^{b}$ Centro de Física da Universidade de Coimbra - CFisUC-CfisUC, Department of Physics, \\ Universidade de Coimbra - UC, Rua Larga, P-3004-516, Coimbra, Portugal. \\ ${ }^{c}$ Centro de Química de Coimbra - CQC, Department of Chemistry, Universidade de Coimbra - UC, \\ Rua Larga, P-3004-535, Coimbra, Portugal. \\ ${ }^{d}$ Centro de Ciências e Tecnologias Nucleares - C ${ }^{2} T N$, Instituto Superior Técnico - IST, \\ Universidade de Lisboa - ULISBOA, 2695-066, Bobadela LRS, Portugal. \\ eAdvanced Materials Laboratory, Escuela Técnica Superior de Ingenierías Agrarias - ETSIIAA, \\ University of Valladolid - UVa, Avenida de Madrid 44, 34004, Palencia, Spain
}

Received: August 7, 2015; Revised: November 27, 2015; Accepted: December 18, 2015

\begin{abstract}
An uranyl complex $\left[\mathrm{UO}_{2}(\mathrm{TFA})_{2}(\mathrm{DMSO})_{3}\right](\mathrm{TFA}=$ deprotonated trifluoroacetic acid; $\mathrm{DMSO}=$ dimethyl sulfoxide) has been successfully synthesized by reacting $\mathrm{UO}_{2}\left(\mathrm{CH}_{3} \mathrm{COO}\right)_{2} \cdot \mathrm{H}_{2} \mathrm{O}$ with one equivalent of $\left(\mathrm{CF}_{3} \mathrm{CO}\right)_{2} \mathrm{O}$ and DMSO. The complex has been characterized by single-crystal X-ray diffraction, X-ray powder diffraction, elemental analysis, FT-IR spectroscopy, thermal analysis and absorption and emission spectroscopies. The spectroscopic properties of the material make it suitable for its application in the sensing and monitoring of uranyl in the PUREX process.
\end{abstract}

Keywords: DMSO, sensing, trifluoroacetate, PUREX, uranyl.

\section{Introduction}

A dimethyl sulfoxide (DMSO) adduct of uranyl trifluoroacetate $\mathrm{UO}_{2}$ (TFA), with a 1:3 composition was synthesized in 1988 by Fomicheva et al., ${ }^{1}$ and its structure in solution was studied by NMR spectroscopy. Nonetheless, no structural elucidation in solid state was conducted. The interest in the solid and solution phases of this complex arise from its easy vacuum sublimation (the necessary condition for the volatility of $\mathrm{UO}_{2}(\mathrm{TFA})_{2}$ is the presence of a strong neutral ligand, such as DMSO) and its applications in the sensing and monitoring of $\mathrm{UO}_{2}{ }^{2+}$ in nuclear processes related to nuclear energy production.

A great deal of work has been dedicated to the development of sensors for actinide ions such as $\left[\mathrm{U}^{\mathrm{VI}} \mathrm{O}_{2}\right]^{2+2-4}$, which have been detected in groundwater around nuclear fuel-processing facilities after underground tests. It should also be noted that monitoring radioactive analytes is now possible using fiber optics, since the $\left[\mathrm{U}^{\mathrm{VI}} \mathrm{O}_{2}\right]^{2+}$ ion shows an intrinsic fluorescence with maxima at 518 and $546 \mathrm{~nm}$, which are compatible with both plastic and glass fibers ${ }^{5,6}$.

Moreover, the PUREX (Plutonium Uranium Redox Extraction) process ${ }^{7,8}$, the de facto standard aqueous nuclear reprocessing method for the recovery of uranium and plutonium from used nuclear fuel, requires continuous monitoring of $\left[\mathrm{U}^{\mathrm{VI}} \mathrm{O}_{2}\right]^{2+}$ ion. This was traditionally achieved by exciting the fluorescence of $\left[\mathrm{U}^{\mathrm{VI}} \mathrm{O}_{2}\right]^{2+}$ ion in nitric acid medium at 337 $\mathrm{nm}$ using a nitrogen laser, since its intensity is strongest in

*e-mail: pmr@unizar.es acidic solution at $\mathrm{pH} 1.6{ }^{9}$. Nowadays, phosphoric acid is additionally added because it complexes the ion, enhances its fluorescence, and thereby lowers the detection limit. Details on the monitoring of uranium in this process can be obtained from Smith et al., ${ }^{9}$ and from Ramanujam ${ }^{10}$.

In this paper we propose the alternative use of trifluoroacetic acid and DMSO to further optimize this application. In trifluoroacetate acid, the emission is particularly intense, being $>150$ times stronger than in water, probably by virtue of the combined effect of lowering the $\mathrm{pH}$ and dehydration by formation of the DMSO complex ${ }^{1}$.

In the work presented herein, evidence of the effective complexation has been gained by X-ray diffraction through structural elucidation of single-crystals of $\left[\mathrm{UO}_{2}(\mathrm{TFA})_{2}(\mathrm{DMSO})_{3}\right]$ $(\mathrm{TFA}=$ deprotonated trifluoroacetic acid; DMSO=dimethyl sulfoxide) isolated from solution (prepared according to a new synthesis method). Further, we present a detailed characterization of the solid form by X-ray powder diffraction, elemental analysis, FT-IR spectroscopy, thermal analysis and absorption and emission spectroscopies.

\section{Experimental}

\subsection{Materials, synthesis and analytical data}

$\left[\mathrm{UO}_{2}(\mathrm{TFA})_{2}(\mathrm{DMSO})_{3}\right](\mathrm{TFA}=$ deprotonated trifluoroacetic acid, $\mathrm{CF}_{3} \mathrm{COOH}$; DMSO=dimethyl sulfoxide, $\left.\left(\mathrm{CH}_{3}\right)_{2} \mathrm{SO}\right)$ was prepared by reacting uranyl acetate hydrate (CAS No. 
6159-44-0, $\geq 98.0 \%$, Sigma-Aldrich), $\mathrm{UO}_{2}\left(\mathrm{CH}_{3} \mathrm{COO}\right)_{2} \cdot \mathrm{H}_{2} \mathrm{O}$, with one equivalent of trifluoroacetic anhydride (CAS No. 407-25-0, $\geq 99 \%$, Sigma-Aldrich), $\left(\mathrm{CF}_{3} \mathrm{CO}\right)_{2} \mathrm{O}$, according the following reaction:

$$
\begin{aligned}
& \mathrm{UO}_{2}\left(\mathrm{CH}_{3} \mathrm{COO}\right)_{2} \cdot \mathrm{H}_{2} \mathrm{O}+\left(\mathrm{CF}_{3} \mathrm{CO}\right)_{2} \mathrm{O} \rightarrow \\
& \mathrm{UO}_{2}\left(\mathrm{CF}_{3} \mathrm{COO}\right)_{2}+2 \mathrm{CH}_{3} \mathrm{COOH}
\end{aligned}
$$

and adding an excess of DMSO (CAS No. 67-68-5, $\geq 99.5 \%$, Sigma-Aldrich).

An alternative method using commercial uranyl nitrate hexahydrate (CAS No. 13520-83-7, $\geq 98.0 \%$, Sigma-Aldrich) as precursor required seven equivalents of $\left(\mathrm{CF}_{3} \mathrm{CO}\right)_{2} \mathrm{O}$ (six for dehydration). Gaseous $\mathrm{N}_{2} \mathrm{O}_{5}$ evolved as nitrate reduction product.

$$
\begin{aligned}
& \mathrm{UO}_{2}\left(\mathrm{NO}_{3}\right)_{2} \cdot 6 \mathrm{H}_{2} \mathrm{O}+7\left(\mathrm{CF}_{3} \mathrm{CO}\right)_{2} \mathrm{O} \\
& \rightarrow \mathrm{UO}_{2}\left(\mathrm{CF}_{3} \mathrm{COO}\right)_{2}+\mathrm{N}_{2} \mathrm{O}_{5} \uparrow+12 \mathrm{CF}_{3} \mathrm{COOH}
\end{aligned}
$$

Both reactions were conducted in DMSO at room temperature (RT) under stirring. The solutions were stored in a refrigerator at $4{ }^{\circ} \mathrm{C}$ for 24 hours. $\left[\mathrm{UO}_{2}\left(\mathrm{CF}_{3} \mathrm{COO}\right)_{2}(\mathrm{DMSO})_{3}\right]$ bright yellow crystals with well-formed crystal faces were formed by slow evaporation. The reaction yield was determined to be higher than $90 \%$ in both synthesis procedures.

$\left[\mathrm{UO}_{2}\left(\mathrm{CF}_{3} \mathrm{COO}\right)_{2}(\mathrm{DMSO})_{3}\right]$ : Chemical formula: $\mathrm{C}_{10} \mathrm{H}_{18} \mathrm{~F}_{6} \mathrm{O}_{9} \mathrm{~S}_{3} \mathrm{U}, M_{\mathrm{w}}:$ 730.46. Anal. Calcd. for $\mathrm{C}_{10} \mathrm{H}_{18} \mathrm{~F}_{6} \mathrm{O}_{9} \mathrm{~S}_{3} \mathrm{U}$ : C, 16.44; H, 2.48; F, 15.61; O, 19.71; S, 13.17; U, 32.59\%. Found: C, 16.24; H, 2.36\%.

\subsection{X-ray crystallographic analysis}

Prior to structural characterization, a powder diffractogram of the sample was obtained using a Bruker D8 Advance Bragg-Brentano diffractometer, in reflection geometry.

For the determination of the crystal structure by X-ray diffraction, several crystals of aforementioned compound were glued to glass fibres and mounted on a Bruker APEX II diffractometer. Several data collections were conducted at room temperature 293(2) K using graphite monochromated $\operatorname{MoK} \alpha(\lambda=0.71073 \AA)$. Empirical absorption corrections were made using SADABS, a program designed to exploit data redundancy to correct 3D-integrated (thin slice) data from Bruker area detectors ${ }^{11}$. None of the data collections yielded good $R_{\text {int }}$ factors. The structure was solved by direct methods using SHELXS-97 ${ }^{12}$ and refined anisotropically (non-H atoms) by full-matrix least-squares on $F^{2}$ using the SHELXL-97 program $^{12}$. The refinement was performed using several DFIX and ISOR constraints. The low quality data and the difference between the scattering power of the atoms involved resulted in unconverging refinements with several signs of disorder in the coordinating ligands. PLATON ${ }^{13}$ was used to analyse the structure and for figure plotting. Atomic coordinates, thermal parameters and bond lengths and angles are provided in the Supporting Information.

\subsection{Physical measurements}

The C, H, N elemental analyses were conducted using a Perkin Elmer CHN 2400 apparatus.

The infrared spectrum was recorded with a Thermo Nicolet 380 FT-IR apparatus equipped with Smart Orbit Diamond ATR system.
Thermal analysis was done with a Perkin-Elmer STA6000, DTA/DTG equipment, by heating the samples in a slow stream of $\mathrm{N}_{2}(20 \mathrm{~mL} / \mathrm{min})$ from room temperature up to $800{ }^{\circ} \mathrm{C}$, with a heating rate of $20^{\circ} \mathrm{C} / \mathrm{min}$.

Optical absorption and photoluminescence spectra were measured at room temperature. The 200-800 nm range diffuse reflectance absorption spectrum in powder form and the absorption spectra in DMSO at different concentrations $\left(10^{-5} \mathrm{M}\right.$ and $\left.10^{-3} \mathrm{M}\right)$ were recorded on a Cary $5000 \mathrm{UV}-\mathrm{Vis}-\mathrm{NIR}$ spectrophotometer. The solid-state photoluminescence spectrum in the visible region was recorded from 450 to $650 \mathrm{~nm}$ with a Horiba-Jobin-Ivon SPEX FluoroLog 3-22 spectrometer using an ozone-free $450 \mathrm{~W}$ Xenon lamp as the excitation source and a Hamamatsu R928 photomultiplier (200-950 nm range) detector, cooled with a Products for Research thermoelectric refrigerated chamber (model PC177CE005).

\section{Results and discussion}

\subsection{Structural description}

The single crystal X-ray diffraction study confirmed a distorted pentagonal-bipyramidal geometry around the $\mathrm{U}$ atoms where the uranyl oxygen atoms occupy the axial positions. Five $\mathrm{O}$ atoms from three dimethyl sulfoxide molecules and two trifluoroacetate ions define the pentagonal plane (Fig. 1, Table 1).

\subsection{X-ray powder diffraction}

Fig. 2 shows the experimental diffraction pattern and the simulated powder diffraction pattern from the single crystal structure using PLATON ${ }^{13}$. There is a good match between simulated and experimental diffractograms: the peaks appear at the predicted theta angles. Differences in intensity can be ascribed to the Bragg-Brentano geometry of the instrument used.

\subsection{Thermal behavior}

Thermal kinetics of $\left[\mathrm{UO}_{2}(\mathrm{TFA})_{2}(\mathrm{DMSO})_{3}\right]$ uranyl trifluoroacetate complex from room temperature to $800{ }^{\circ} \mathrm{C}$ involved a melting point around $100{ }^{\circ} \mathrm{C}$ (endotherm at $103{ }^{\circ} \mathrm{C}$ ) and a decomposition in two stages at $105-300{ }^{\circ} \mathrm{C}$

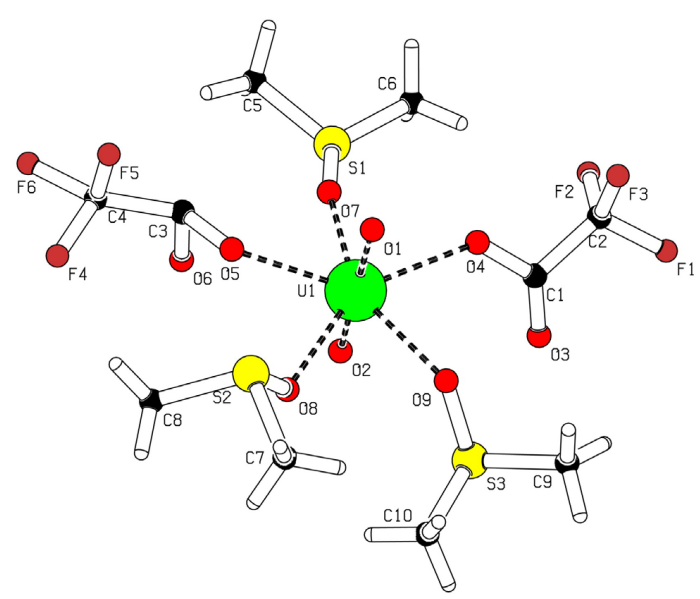

Fig. 1. Structural diagram of $\left[\mathrm{UO}_{2}(\mathrm{TFA})_{2}(\mathrm{DMSO})_{3}\right]$ complex. 
Table 1. Crystal data and structure refinement for $\left[\mathrm{UO}_{2}(\mathrm{TFA})_{2}(\mathrm{DMSO})_{3}\right]$ complex.

\begin{tabular}{|c|c|}
\hline Complex & {$\left[\mathrm{UO}_{2}(\mathrm{TFA})_{2}(\mathrm{DMSO})_{3}\right]$} \\
\hline Empirical formula & $\mathrm{C}_{10} \mathrm{H}_{18} \mathrm{~F}_{6} \mathrm{O}_{9} \mathrm{~S}_{3} \mathrm{U}$ \\
\hline Formula weight & 730.45 \\
\hline Temperature (K) & 293(3) \\
\hline Wavelength $(\AA)$ & 0.71073 \\
\hline Crystal system & Orthorhombic \\
\hline Space group & Pbca \\
\hline$a(\AA)$ & $14.8559(13)$ \\
\hline$b(\AA)$ & $13.6663(11)$ \\
\hline$c(\AA)$ & 21.8881(18) \\
\hline$\alpha\left({ }^{\circ}\right)$ & 90.00 \\
\hline$\beta\left(\left(^{\circ}\right)\right.$ & 90.00 \\
\hline$\gamma\left({ }^{\circ}\right)$ & 90.00 \\
\hline Volume $\left(\AA^{3}\right)$ & $4443.8(6)$ \\
\hline $\mathrm{Z}$ & 8 \\
\hline $\begin{array}{l}\text { Calculated density (g } \\
\mathrm{cm}^{-3} \text { ) }\end{array}$ & 2.184 \\
\hline $\begin{array}{l}\text { Absorption coefficient } \\
\left(\mathrm{mm}^{-1}\right)\end{array}$ & 7.673 \\
\hline$F(000)$ & 2752 \\
\hline $\begin{array}{l}\theta \text { range for data } \\
\text { collection }\end{array}$ & $2.23-25.94$ \\
\hline Index ranges $\left({ }^{\circ}\right)$ & $-18<h<18 ;-16<k<16 ;-26<l<26$ \\
\hline Reflections collected & 87413 \\
\hline Independent reflections & 4299 \\
\hline Completeness to $2 \theta=51^{\circ}$ & 0.990 \\
\hline Refinement method & Full matrix LS on $\mathrm{F}^{2}$ \\
\hline $\begin{array}{l}\text { Data/restrains/ } \\
\text { parameters }\end{array}$ & $4299 / 63 / 263$ \\
\hline Goodness-of-fit on $\mathrm{F}^{2}$ & 1.023 \\
\hline Final $R$ indices $[I>2 \sigma(I)]$ & $R=0.0891 ; \mathrm{w} R=0.2475$ \\
\hline$R$ indices (all data) & $R=0.1985 ; \mathrm{w} R=0.3397$ \\
\hline $\begin{array}{l}\text { Largest diff. peak and } \\
\text { hole }\end{array}$ & $-2.854 / 2.237$ \\
\hline
\end{tabular}

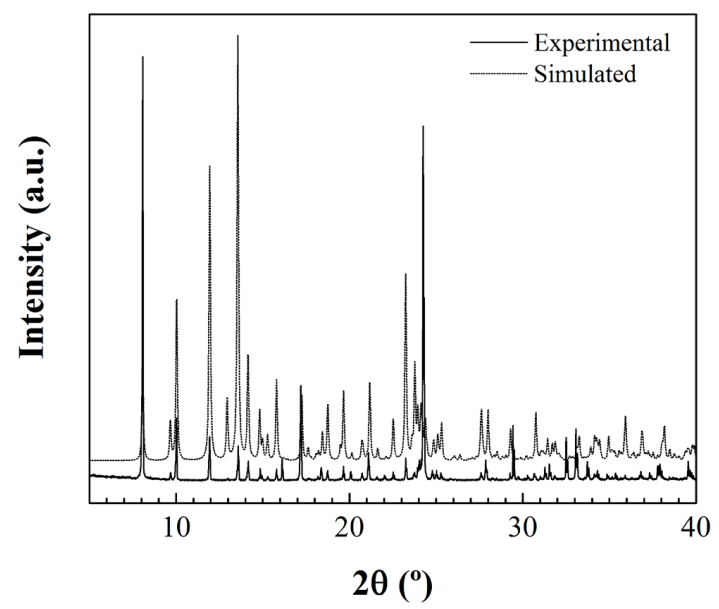

Fig. 2. Experimental (solid line) vs. calculated (dashed line) X-ray powder diffraction patterns for $\left[\mathrm{UO}_{2}(\mathrm{TFA})_{2}(\mathrm{DMSO})_{3}\right]$ complex. and at $300-345^{\circ} \mathrm{C}$ sensitized by two exotherms at $245.8^{\circ} \mathrm{C}$ and $339.7{ }^{\circ} \mathrm{C}$, respectively (Fig. 3). The weight loss for these stages corresponded to partial and final removal of DMSO and trifluoroacetate ligands. This overall weight loss (ca. $62 \%$ ), corresponds to the formation of $\mathrm{U}_{3} \mathrm{O}_{8}$. The final exotherm at ca. $550{ }^{\circ} \mathrm{C}$ can be attributed to decomposition of $\mathrm{U}_{3} \mathrm{O}_{8}$ to $\mathrm{UO}_{2}$, the expected final decomposition product in inert atmosphere, leading to an overall weight loss of $63 \%$.

Since the exothermic effect at $340{ }^{\circ} \mathrm{C}$ can be attributed to vaporization and this temperature is lower than that reported for uranyl trifluoroacetate in absence of $\mathrm{DMSO}^{1}$, the complex with DSMO can be deemed as more suitable for vacuum sublimation.

\subsection{Vibrational spectra}

The main infrared bands are summarized in Table 2 . Those at 935 and $907 \mathrm{~cm}^{-1}$ are attributed to the $v_{3}\left(\mathrm{UO}_{2}{ }^{2+}\right)$ stretching vibrations (Fig. 4). This doubling of the $\mathrm{UO}_{2}^{2+}$ asymmetric stretching vibrations is also reflected in the $\mathrm{UO}_{2}{ }^{2+}$ symmetric stretching region, where two bands are observed at 833 and $792 \mathrm{~cm}^{-1}$. The band below $540 \mathrm{~cm}^{-1}$ may be attributed to the $v\left(\mathrm{U}-\mathrm{O}_{\text {equatorial }}\right)$ unit vibrations. It should be noted that characteristic vibrations of uranyl ions and trifluoroacetate groups overlap, so they cannot be clearly separated without structure-based calculations.

The absorption peaks at $1683 \mathrm{~cm}^{-1}$ and $1418 \mathrm{~cm}^{-1}$ establish the presence of $\mathrm{COO}^{-}$asymmetric and symmetric stretching, respectively. $\Delta v=v(\mathrm{COO}-)_{\text {as }}-v(\mathrm{COO}-)_{\mathrm{s}}=265 \mathrm{~cm}^{-1}$ is a high value, in agreement with unidentate coordination. The peak at $1180 \mathrm{~cm}^{-1}$ is assigned to $\mathrm{CF}$ stretching vibrations of the $\mathrm{CF}_{3}$ group. The band at $907 \mathrm{~cm}^{-1}$ represents the $\mathrm{C}-\mathrm{C}$ stretching. The next band at $833 \mathrm{~cm}^{-1}$ is due to $\mathrm{COO}^{-}$rocking, while $\mathrm{CH}_{2}$ rocking is seen in the next absorption band at $792 \mathrm{~cm}^{-}$ ${ }^{1}$. The characteristic band for COO- scissoring is observed at $716 \mathrm{~cm}^{-1}$.

Dimethyl sulfoxide is structurally similar to acetone, with a sulfur replacing the carbonyl carbon. The normal absorption of the $\mathrm{S}=\mathrm{O}$ bond occurs at $1050 \mathrm{~cm}^{-1}$ but under coordination it appears at $1030 \mathrm{~cm}^{-1}$. Symmetric bending vibration of $\mathrm{CH}_{3}$ groups gives rise to a major band at around $1420 \mathrm{~cm}^{-1}$.

\subsection{Optical properties}

The UV-Vis absorption spectrum in $10^{-5} \mathrm{M}$ DMSO solution (Fig. 5) shows a main absorption peak at $260 \mathrm{~nm}$, associated to the $\pi-\pi^{*}$ absorption from the TFA ligand

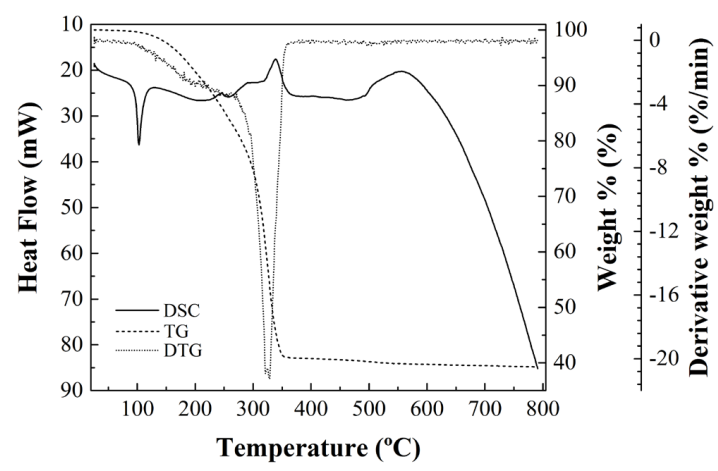

Fig. 3. TG/DTG and DSC curves for $\left[\mathrm{UO}_{2}(\mathrm{TFA})_{2}(\mathrm{DMSO})_{3}\right]$ complex. 


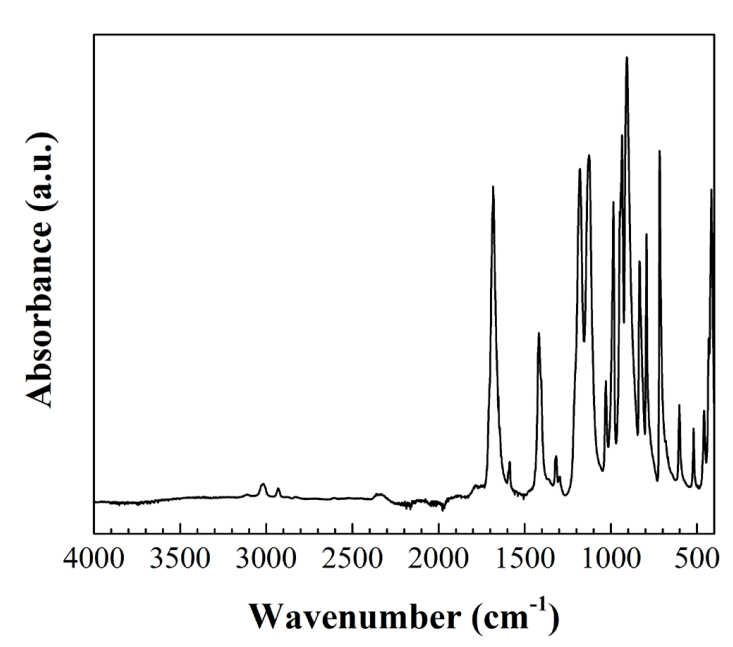

Fig. 4. ATR-FTIR spectrum of $\left[\mathrm{UO}_{2}(\mathrm{TFA})_{2}(\mathrm{DMSO})_{3}\right]$.

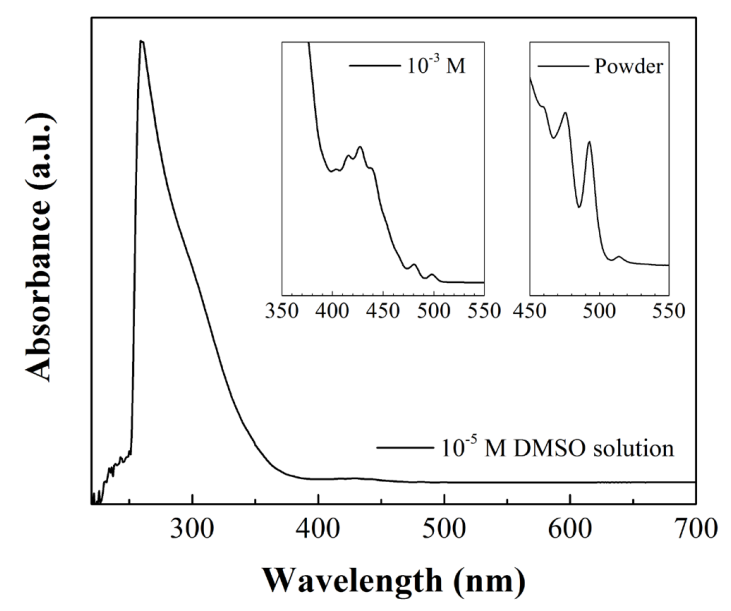

Fig. 5. Absorption spectrum of $\left[\mathrm{UO}_{2}(\mathrm{TFA})_{2}(\mathrm{DMSO})_{3}\right]$ in a $10^{-5} \mathrm{M}$ DMSO solution. Left inset: detail of the absorption spectrum in a $10^{-3} \mathrm{M}$ DMSO solution. Right inset: detail of the diffuse reflectance spectrum in powder form.

(similar to those observed for sodium trifluoroacetate or ammonium trifluoroacetate), plus several $\left[\mathrm{U}^{\mathrm{VI}} \mathrm{O} 2\right]^{2+}$ weaker bands that can distinguished in greater detail by increasing the concentration of the DMSO solution to $10^{-3} \mathrm{M}$ or by UV-Vis diffuse reflectance measurements in powder form (see insets in Fig. 5). These bands start at $495 \mathrm{~nm}$ and continue well into the UV range, arising from partially forbidden charge transfer transitions from oxo-based molecular orbitals to non-bonding, unoccupied $f$-orbitals. Several peaks at 403 , 414, 426, 438, 476 and $493 \mathrm{~nm}$ can be readily discerned, although the overlap with the strong TFA absorption band precludes the deconvolution into the actual fourteen discrete absorption bands.

With regard to the emission spectra, both the ligand-mediated excitation at $305 \mathrm{~nm}$ (chosen so as to avoid that the second harmonic of the laser would fall within the range of the uranyl fluorescence spectrum) and the direct excitation at $420 \mathrm{~nm}$ resulted in the characteristic uranyl emission centered at $525 \mathrm{~nm}$ (Fig. 6). Strong coupling of the electronic energy

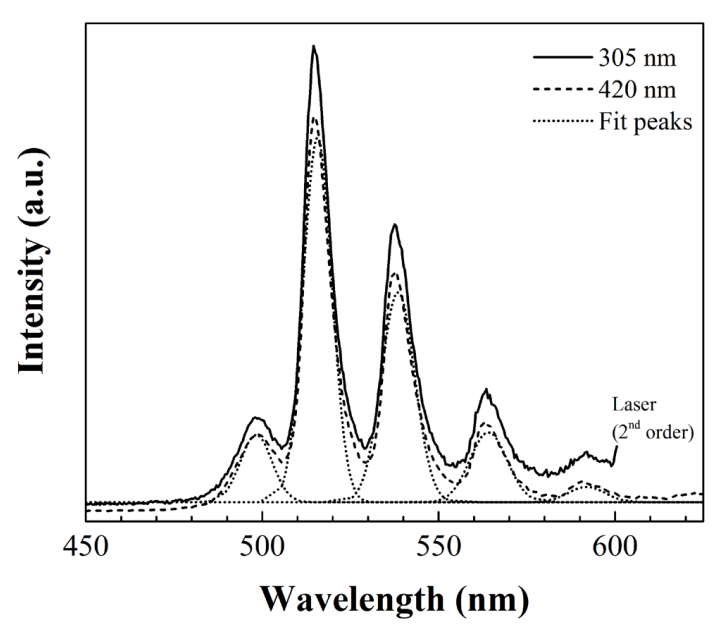

Fig. 6. Emission spectra of $\left[\mathrm{UO}_{2}(\mathrm{TFA})_{2}(\mathrm{DMSO})_{3}\right]$ upon excitation at $305 \mathrm{~nm}$ (black) and at $420 \mathrm{~nm}$ (red).

Table 2. Main absorption bands in the ATR-FTIR spectrum of $\left[\mathrm{UO}_{2}(\mathrm{TFA})_{2}(\mathrm{DMSO})_{3}\right]$

\begin{tabular}{|c|c|c|}
\hline $\begin{array}{l}\text { Wavenumber } \\
\left(\mathrm{cm}^{-1}\right)\end{array}$ & Main assignation & $\begin{array}{l}\text { Alternative } \\
\text { assignation }\end{array}$ \\
\hline 3017 & $\begin{array}{l}\mathrm{CH}_{3} \text { asymmetric } \\
\text { stretching vibration }\end{array}$ & \\
\hline 2930 & $\begin{array}{l}\mathrm{CH}_{3} \text { symmetric } \\
\text { stretching vibration }\end{array}$ & \\
\hline 2358 & Overtone of $1179 \mathrm{~cm}^{-1}$ & \\
\hline 1683 & $\begin{array}{l}\mathrm{COO}^{-} \text {asymmetric } \\
\text { stretching }\end{array}$ & \\
\hline 1587 & Overtone of $792 \mathrm{~cm}^{-1}$ & \\
\hline 1418 & $\begin{array}{l}\mathrm{COO}^{-} \text {symmetric } \\
\text { stretching }\end{array}$ & $\begin{array}{l}\mathrm{CH}_{3} \text { symmetric } \\
\text { bending vibration }\end{array}$ \\
\hline 1179 & CF stretching vibrations & \\
\hline 1029 & $\mathrm{~S}=\mathrm{O}$ stretching & \\
\hline 985 & C-S & \\
\hline 935 & $\begin{array}{l}v_{3} \mathrm{O}=\mathrm{U}=\mathrm{O} \text { asymmetric } \\
\text { stretching vibration }\end{array}$ & $\mathrm{COO}^{-}$waging \\
\hline 907 & $\begin{array}{l}v_{3} \mathrm{O}=\mathrm{U}=\mathrm{O} \text { asymmetric } \\
\text { stretching vibration }\end{array}$ & C-C stretching \\
\hline 833 & $\begin{array}{l}v_{1} \mathrm{O}=\mathrm{U}=\mathrm{O} \text { symmetric } \\
\text { stretching vibration }\end{array}$ & COO- rocking \\
\hline 792 & $\begin{array}{l}v_{1} \mathrm{O}=\mathrm{U}=\mathrm{O} \text { symmetric } \\
\text { stretching vibration }\end{array}$ & $\begin{array}{l}\text { C-C stretching // } \\
\text { C-S stretching }\end{array}$ \\
\hline 603 & TFA & \\
\hline 459 & U-O vibrations & \\
\hline 432 & U-O vibrations & \\
\hline
\end{tabular}

levels with the symmetric $\mathrm{O}=\mathrm{U}=\mathrm{O}$ stretching mode leads to a vibronically resolved spectrum with several distinct emission bands between 450 and $650 \mathrm{~nm}$. The shape of the system is species dependent and highly coupled to the chemical environment, thus allowing this technique (laser induced fluorescence spectroscopy) to probe the local environment and speciation.

The lifetime measurements (not shown) are in agreement with those previously reported by Fomicheva et al., ${ }^{1}$ with $\tau>200 \mu$ s at RT (although lowering the temperature is known to cause an exponential increase of the quantum yield). 
This long lifetime is a result of the advantageous choice of trifluoroacetic acid, which ensures an acidic medium (avoiding chloride, bromide and iodide ions, associated to quenching), and the use of trifluoroacetic anhydride in the synthesis procedure, which precludes any water-associated quenching.

\section{Conclusions}

$\left[\mathrm{UO}_{2}(\mathrm{TFA})_{2}(\mathrm{DMSO})_{3}\right](\mathrm{TFA}=$ deprotonated trifluoroacetic acid; $\mathrm{DMSO}=$ dimethyl sulfoxide), a promising material for $\left[\mathrm{U}^{\mathrm{VI}} \mathrm{O}_{2}\right]^{2+}$ sensing and monitoring, has been prepared according to a new synthesis method and the structure of the complex has been elucidated by single-crystal X-ray diffraction. Thermal analyses, by TG and DSC, suggest its suitability to vacuum sublimation. The inherent photophysical properties of the uranyl cation have been assayed by absorption and emission spectroscopies, confirming an intense green emission

\section{References}

1. Fomicheva EA, Sidorenko GV, Shcherbakova LL. Volatile adducts of uranyl trifluoroacetate. Soviet Radiochemistry (English Translation). 1988;29(6):664-670.

2. Verga Scheggi AM, McFarlane R, Hamilton MC. A fluorescence based dissolved oxygen sensor. In: SPIE 0798. Fiber Optic Sensors II. Proceedings. The Hague, Netherlands: SPIE; 1987. p. 324-330.

3. Malstrom RA, Hirschfeld T. On-Line uranium determination using remote fiber fluorimetry. In: 26th Conference on Analytical Chemistry in Energy Technology. Analytical Spectroscopy, Analytical Chemistry. Proceedings. Knoxville, TN: Elsevier; 1984. p. 25-30. (Symposia Series).

4. Boisdé G, Blanc E, Mauchien P, Perez JJ. Fiber optic chemical sensors in nuclear power plants. In: Wolfbeis OS, editor. Fiber optic chemical sensors and biosensors. Boca Raton: CRC Press; 1991. p. 135-149.

5. Sporea D, Sporea A, Okeeffe S, McCarthy D, Lewis E. Optical fibers and optical fiber sensors used in radiation monitoring. In: Yasin M, Harun SW, Arof H, editors. Selected Topics on Optical Fiber Technology. Rijeka, Croatia: InTech; 2012. p. 668.

6. Trettnak W, Hofer M, Wolfbeis OS. Applications of optochemical sensors for measuring environmental and biochemical resulting from the combined effect of lowering the $\mathrm{pH}$ and dehydration by formation of the DMSO complex, previously reported by other groups. This can provide a convenient means of monitoring uranyl concentration, speciation, and movement without the need for additional imaging agents (such as dye probes).

\section{Acknowledgements}

Access to TAIL-UC facility funded under QREN-Mais Centro project ICT-2009-02-012-1980 is gratefully acknowledged. P.M.-R. would like to gratefully acknowledge the financial support of Santander Universidades through "Becas Iberoamérica Jóvenes Profesores e Investigadores. España 2015" scholarship program. C2TN/IST authors gratefully acknowledge the FCT support through the UID/Multi/04349/2013 project.

quantities. In: Gopel W, Hesse J, Zemel JN, editors. Sensors set: a comprehensive survey. Weinheim, Germany: Wiley-VCH Verlag; 1995. p. 931-967.

7. Anderson HH, Asprey LB. Solvent extraction process for plutonium. US patent 2924506 A; 1960.

8. Burns JH. Solvent-extraction complexes of the uranyl ion. 2. Crystal and molecular structures of catena-bis(m-di-n-butyl phosphato-O,O')dioxouranium(VI) and bis(m-di-n-butyl phosphato-O,O')bis[(nitrato)(tri-n-butylphosphine oxide) dioxouranium(VI)]. Inorganic Chemistry. 1983;22(8):11741178. DOI: $10.1021 / \mathrm{ic} 00150 \mathrm{a} 006$

9. Smith NA, Cerefice GS, Czerwinski KR. Fluorescence and absorbance spectroscopy of the uranyl ion in nitric acid for process monitoring applications. Journal of Radioanalytical and Nuclear Chemistry. 2012; 295(2):1553-1560.

10. Ramanujam A. An introduction to the PUREX process. IANCAS. 1998; 14(2):11-20.

11. Sheldrick G. SADABS. Göttingen, Germany: University of Göttingen; 1996.

12. Sheldrick GM. A short history of SHELX. Acta Crystallographica. Section A. 2007;64(1):112-122. doi:10.1107/S0108767307043930

13. Spek AL. Single-crystal structure validation with the program PLATON. Journal of Applied Crystallography. 2003;36(1):713. doi:10.1107/S0021889802022112 